\title{
DESMIDS BIODIVERSITY IN FRESHWATER PONDS OF DISTRICT NAGAUR, WESTERN RAJASTHAN INDIA: A PRELIMINARY INVESTIGATION
}

\author{
Abhilasha Choudhary ${ }^{1 *}$, Moolchand Mali ${ }^{1}$, Ranveer Singh ${ }^{2}$, Dinesh Kumar Singh ${ }^{3}$ \\ ${ }^{1}$ Department of Botany, M. L. B. Government College, Nokha (Bikaner), Rajasthan, India. \\ ${ }^{2}$ Department of Chemistry, M. L. B. Government College, Nokha (Bikaner) Rajasthan, India. \\ ${ }^{3}$ Department of Botany, Shri Jagdishprasad Jhabarmal Tibrewala University, Jhunjhunu, Rajasthan, India. \\ Received - April 16, 2021; Revision - May 26, 2021; Accepted - June 09, 2021 \\ Available Online - June 25, 2021
}

DOI: http://dx.doi.org/10.18006/2021.9(3).369.377

KEYWORDS
Desmids
Nagaur
Jhada Talab
Limnological Investigation

* Corresponding author

E-mail: abhishiv25@gmail.com (Abhilasha Choudhary)

Peer review under responsibility of Journal of Experimental Biology and Agricultural Sciences.

Production and Hosting by Horizon Publisher India [HPI] (http://www.horizonpublisherindia.in/).

All rights reserved.

\begin{abstract}
The present study was carried out to investigate the desmids biodiversity in traditional freshwater reservoirs of Nagaur district, Western Rajasthan, India. The samples were collected in January 2021 from the freshwater small ponds which harvests rainwater located in and around Nagaur city. These samples were analyzed by following the standard method prescribed by A.P.H.A for assessing the various physicochemical parameters such as $\mathrm{pH}$, TDS, Fluoride, Nitrate, Chloride, total alkalinity, and total hardness to check drinking water quality and for ecological assessment. Furthermore desmids species-level identification and description have been done with the help of standard literatures and monographs. Results of physicochemical parameters indicate the deteriorating drinking water quality of all four sampling sites. In the present study total of 16 species belong to 5 genera i.e. Netrium, Closterium, Cosmerium, Staurastrum, and Eustrum of desmids have been recorded for the first time from the freshwater ponds located in or around the Nagaur city. The higher biodiversity of Closterium and Cosmarium species at Jhada talab confirm its significant relationship with high calcium and nutrient-rich water quality. While low biodiversity of desmids at remaining all village ponds indicates that high $\mathrm{pH}$ and oligotrophic quality decreases the desmids biodiversity. Results of this study might be helpful to assess the geographic distribution of desmids flora of Nagaur district and establish water quality of protected freshwater habitats as well as in updating the list of current species of desmids in this sub-region.
\end{abstract}

All the articles published by Journal of Experimental Biology and Agricultural Sciences are licensed under a Creative Commons Attribution-NonCommercial 4.0 International License Based on a work at www.jebas.org.

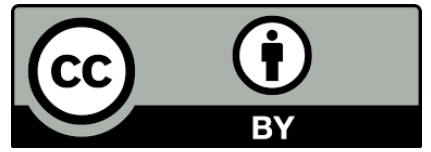




\section{Introduction}

Freshwater algae are a major group of photoautotrophs that has a big share in biodiversity on the earth and each species takes part in the aquatic ecosystem. Desmids are green unicellular and filamentous microscopic algae that are made up of two symmetrical semi cells (Coesel \& Meesters, 2007). Desmids are rich in biodiversity and about 2,943 species are taxonomically recorded in this family (Guiry \& Guiry, 2021). These advanced green algae can be present in benthic periphyton populations and planktonic communities and contributing to food chain dynamics (Coesel \& Krienitz, 2007). British Desmidiaceae by Ralfs (1848) was the earliest book for the identification of desmids. In India, the earlier important research work on desmids has been carried out by Agarkar et al. (1983), and Hegde (1986). Further, Habib (2003) provided a detailed account of desmids biodiversity from various areas of India. Phytoplankton investigation and desmids genera of the arid sub-region of Bikaner Rajasthan were extensively studied and well documented by Mali \& Barupal (2016), Mali \& Rohitash (2017), Mali \& Rohitash (2018), Rohitash \& Mali (2021).

Oligotrophic water bodies that have a lower level of nitrate, phosphate, and $\mathrm{pH}$ have been found low productive to the desmids, while most of the species of Closterium, Cosmarium, and Staurastrum genera have been found in eutrophic water condition (Coesel, 1983; Stamencovic \& Cvijan, 2008). Further, Palmer (1969) revealed that Closterium sp. is a good indicator of polluted water. Desmids are ecologically sensitive microalgae that function as useful water quality indicators. Trying to protect microscopic organisms is a challenge due to taxonomic barriers as well as insufficient knowledge of ecology and distribution (Wilbraham, 2020). Similarly, the findings of Neustupa \& Woodard (2020) revealed that quantitative changes in desmids morphological variation could be used as pollution indicators.

The Aravali, one of the oldest mountain ranges of the world divides the state of Rajasthan into two distinct physiographic areas i.e. Eastern and Western Rajasthan. The western part of Aravali which is western Rajasthan covers an average of $60 \%$ of the great Thar Desert of India. Whereas the area towards the south and the southeastern part is a sub-humid zone supporting forest type of vegetation (Pachori \& Kumar, 2017). Barmer, Jaisalmer, Bikaner, Nagaur, Jodhpur, Shriganganagar, and Churu are the major districts of the western Rajasthan with short monsoon rainfall which making these reason most water-deficient regions of the country. The total annual rainfall of the Thar Desert is $251 \mathrm{~mm}$ with a coefficient of variation of $38 \%$ (Singh \& Chauhan 2014). One survey made by the CAZRI revealed that Nadis and Talab (Natural water harvesting sources) fulfills $13.18 \%$ of the total water demand of the Nagaur district and are still the main freshwater sources, providing comfort for wildlife and domestic uses for humans and livestock (Saxena, 2017). In Nagaur, limnological research work is overlooked and very rare knowledge of the aquatic environment can be found so, there is a strong need for limnological analysis of conventional freshwater bodies. Desmids are ecologically sensitive green microalgae and can be used as a bioindicator in water quality assessments. This region is lacking behind in microfloral investigation therefore this study related to desmids flora of conventional freshwater bodies has been carried out.

\section{Materials and Methods}

Study area Nagaur district is a part of the Great Indian Thar Desert that lies between $26^{\circ} 25^{\prime} \& 27^{\circ} 40^{\prime}$ North Latitude \& $73^{\circ} 10^{\prime} \& 75^{\circ} 5^{\prime}$ East Longitude. Its climate is very harsh for human habitation, with diurnal and annual temperature extremes, intense drought followed by high wind velocity, and lower relative humidity. For this study, four sampling sites were selected, among these, the first sampling water reservoir was natural and ancient Jhada talab located in Nagaur city and the other 3 sampling sites were manmade small ponds that are called Talab or Nadi in the local language. Jhada talab is an ancient water source and it was being used as a drinking water resource by the end of the 21 st century. Rest three village ponds are Imarti Nadi Chimrani (POND A), Chimrani village Nadi (POND B), and Bungri Mata Mandir Nadi Kharnal village (POND C) at the distance of $10 \mathrm{~km}, 12 \mathrm{~km}$ and 17 $\mathrm{km}$ from Nagaur city respectively. These are small but important water reservoirs that are managed and utilized by the local village community and quench the thirst for 8 to 10 months (Saxena, 2017). In the current study, sampling was carried out in January 2021.

\subsection{Physicochemical analysis}

Small ponds can be affected by little environmental changes therefore physicochemical parameters investigation is essential in limnological studies. Clean glass stopper bottles were used for water sample collection from all sampling sites. The physicochemical parameters such as $\mathrm{pH}$, TDS, Fluoride, Nitrate, Chloride, total alkalinity, and total hardness were analyzed by following standard methods of A.P.H.A (Baird \& Bridgewater 2017). The $\mathrm{pH}$ was measured by a digital $\mathrm{pH}$ meter while TDS was measured by the turbidity meter. The trimetric method was used to analyze total alkalinity, total hardness (calcium and magnesium), and Chloride. Fluoride and nitrate were analyzed by ion selective electrode and spectrophotometric methods.

\subsection{Estimations of Desmids population}

For desmids analysis, algal samples were collected in January 2021 selected from all the selected sites of water ponds. Water samples having an algal presence were collected from the surface water and deep water body from all the selected sampling sites. Planktons were captured by plankton net $(40 \mu \mathrm{m})$ and stored in a wide 
opening bottle. A $4 \%$ formalin solution was used as a preservative for the immediate preservation of the collected samples. The samples were preserved and taxonomic analysis of algal material was performed in the Department of Botany, Government College Nokha, Bikaner, Rajasthan (India). Morphological examinations of desmids were studied using a research light microscope with 150x and 600x magnification and photomicrographs were taken with Sony digital camera (Cyber-Shot DSC-W210). The size of algae was measured with a stage ocular micrometer. Standard keys and literature such as West \& West, 1912; Prescott, 1976; Turner, 1978; Coesel \& Meesters, 2007 were used for the identification of desmids genera. $\mathrm{mg} / \mathrm{l}, 4-68 \mathrm{mg} / \mathrm{l}, 10-88 \mathrm{mg} / \mathrm{l}$ and $20-220 \mathrm{mg} / \mathrm{l}$ while the B.I.S suggested limits for these minerals is $250 \mathrm{mg} / 1,1.0 \mathrm{mg} / \mathrm{l}, 550 \mathrm{mg} / \mathrm{l}$, $75 \mathrm{mg} / \mathrm{l}$ and $30 \mathrm{mg} / \mathrm{l}$ respectively. Compilation of study results suggested that physicochemical parameters of village ponds didn't show much variation but the water quality of these four ponds is not as per the B.I.S. standard of drinking water (Table 1).

\subsection{Identification of Desmids genera}

The freshwater samples collected from the selected water bodies located in or around the Nagaur city were taken for microscopic observation. Results of microscopic analysis suggested the presence of 16 species belonging to 5 genera of desmids, the

Table 1 Physicochemical properties of the water samples collected from the sampling sites and its comparison with Indian drinking water standard as proposed by B.I.S. (2012)

\begin{tabular}{|c|c|c|c|c|c|}
\hline Physicochemical Parameters & Jhada Talab & Pond A & Pond B & Pond C & $\begin{array}{l}\text { Drinking water } \\
\text { acceptable limit } \\
\text { (B.I.S 2012) }\end{array}$ \\
\hline $\mathrm{pH}$ & 8.20 & 8.7 & 9.16 & 8.78 & $6.5-8.5$ \\
\hline TDS (mg/L) & 1280 & 130 & 110 & 116 & 500 \\
\hline Total Alkanity (mg/L) & 220 & 50 & 30 & 40 & 200 \\
\hline Total Hardness (mg/L) & 550 & 40 & 30 & 40 & 200 \\
\hline Chloride (mg/L) & 400 & 20 & 20 & 30 & 250 \\
\hline Fluride (mg/L) & 1.20 & 0.140 & 0.126 & 0.132 & 1.0 \\
\hline Nitrate (mg/L) & 68 & 6 & 4 & 5 & 45 \\
\hline Calcium (mg/L) & 88 & 20 & 10 & 20 & 75 \\
\hline Magnesium (mg/L) & 79 & 20 & 20 & 20 & 30 \\
\hline
\end{tabular}

\section{Results}

\subsection{Physico-chemical characteristic of the sampling site water}

In this research, physicochemical parameters of the collected water samples from all the selected sites were analyzed in terms of water quality, and the obtained results were compared with Indian standard drinking water acceptable limits proposed by the Bureau of Indian standard (IS: 10500; 2012). The minimum pH was reported from the water samples collected from the Jhada talab (8.20) and the maximum $\mathrm{pH}$ was reported from the water samples collected from the pond B (9.16) while the standard range was suggested between 6.5 to 8.5 for drinking water. For the collected water samples, TDS ranged from $110-1280 \mathrm{mg} / \mathrm{l}$ and the standard acceptable limit TDS is $500 \mathrm{mg} / \mathrm{l}$. Furthermore, total alkalinity and total hardness were recorded between 30 to $220 \mathrm{mg} / 1$ and $30-300$ $\mathrm{mg} / \mathrm{l}$ respectively for the collected water samples, and as per the B.I.S. standard maximum acceptable limit is $200 \mathrm{mg} / \mathrm{l}$ and 550 $\mathrm{mg} / \mathrm{l}$ respectively. For all the samples collected from four sampling sites the concentration of chloride, fluoride, nitrate, calcium, and magnesium was reported in the range of $20-420 \mathrm{mg} / \mathrm{l}, 0.12-1.20$ details of morphological identifications of the identified species are given below (Abbreviations - L-Long; W - Wide, I-Ishathmus).

\section{Family - Mesotaeniaceae}

Netrium digitus (Brébisson ex Ralfs) Itzigsohn \& Rothe: (Coesel $\&$ Meesters, 2007)

Cell morphometry $-\mathrm{L}=99-227.7 \mu \mathrm{m}, \mathrm{W}=29.7-67.2 \mu \mathrm{m}$, L/W=3.0, chloroplast have 6 laminae (Plate A, Figure 1): Occurrence - Jhada Talab.

\section{Family - Closteriaceae}

Closterium acerosum (Schroeder) Ehr.: (Coesel \& Meesters, 2007)

Cells fusiform, variable in size, apices rounded, cell wall finely striate, yellowish-brown, ridged chloroplast with 6-7 pyrenoids (Plate A; Figure 2 \& 3)

Cell Morphometry - L - 471.5-502.8 $\mu \mathrm{m}, \mathrm{W}-50.1-71.2 \mu \mathrm{m}$; Occurrence - Jhada Talab 
Closterium attenuatum Ralfs: (Coesel \& Meesters, 2007)

Curved frond, attenuated, abruptly contract a conical point, reddish empty frond, finely striated.

Cell Morphometry - L - 340-550 $\mu \mathrm{m}, \mathrm{W}-28-50 \mu \mathrm{m}, \mathrm{L} / \mathrm{Br}-10-18 \mu \mathrm{m}$ (Plate A, Figure 4): Occurrence -Jhada Talab

Closterium cynthia De Notaris Species [var. Cynthia]: (Coesel \& Meesters, 2007)

Cell small, strongly curved, inner side concave or straight at the central region, brown color cell wall.

Cell Morphometry - L -73-180 $\mu \mathrm{m}, \mathrm{W}-11-22 \mu \mathrm{m}$ wide, $\mathrm{L} / \mathrm{W}=8-10$, striated finely (10-11 striae/10 $\mu \mathrm{m})$ (Plate A, Figure 5): Occurrence -POND A

Closterium pseudo lunula Borge: (Coesel \& Meesters, 2007)

Cells 6-8 times wide, straight, elliptic to fusiform, slightly convex, ventral margin straight, apex truncated and-rounded, Cell wall smooth, Chloroplast axial, pyrenoid not found.

Cell Morphometry - L - 290-340 $\mu \mathrm{m}, \mathrm{W}-45-47 \mu \mathrm{m}$ (Plate A, Figure 6); Occurrence - Jhada Talab

\section{Family: Desmidiaceae}

Cosmarium blyttii Wille: (Coesel \& Meesters, 2007)

Undulated lateral and apical margin, semi cell granules in a centra one ring or one granule

Cell Morphometry - L- Cells 25-33 $\mu \mathrm{m}, \mathrm{W}-24 \mu \mathrm{m}$, I-. 5.5-6 $\mu \mathrm{m}$ (Plate B, Figure 7); Occurrence -Jhada Talab

Cosmarium botrytis; Meneghini ex Ralfs 1848: (Coesel \& Meesters, 2007)

Semi-cells are pyramidal, with a rounded basal corner, flattened or slightly convex apex, and granules organized evenly on the side cell wall.

Cell Morphometry - L-56--95 $\mu \mathrm{m}, \mathrm{W}-50--68 \mu \mathrm{m}, \mathrm{I}-14-24 \mu \mathrm{m}$ (Plate B, Figure 8-9); Occurrence - Jhada Talab

Cosmarium crenatum Ralfs ex Ralfs 1848: (Coesel \& Meesters, 2007)

Frond punctuated, deeply constricted at the middle, segments crenate at the margin and flattened at the end; spines of sporangia short.

Cell Morphometry - L- 26-26.5 $\mu \mathrm{m}, \mathrm{W}-17-18 \mu \mathrm{m}, \mathrm{I}-6-7 \mu \mathrm{m}$ (Plate B, Figure 10): Occurrence -Jhada Talab
Cosmarium granatum Brébisson: (Ralfs 1848; Coesel \& Meesters, 2007)

Small cell size, semi cells are pyramidal, apex flattened, side view elliptical and ovoid, cell wall dotted.

Cell Morphometry - L-22.5-47 $\mu \mathrm{m}, \mathrm{W}-15.4-30 \mu \mathrm{m}, \mathrm{I}-$ 5.6-8.6 $\mu \mathrm{m}$

(Plate B, Figure 11): Occurrence -Jhada Talab

Cosmarium formosulum Hoffmann Species [var. formosulum]: (Coesel \& Meesters, 2007)

Cell body small, trapezoid in shape, basal margins broadly rounded, both side crenated apex slightly wavy, cell wall granulated, granules on each ridge.

Cell Morphometry - L- 40-50 $\mu \mathrm{m}$ long, W-34-40 $\mu \mathrm{m}, \mathrm{I}-10-15.5 \mu \mathrm{m}$ (Plate B, Figure 12-13): Occurrence -Jhada Talab

Cosmarium impressulum Elfving: (Coesel \& Meesters, 2007)

Small cell with a smooth wall, four wavy margins, all waves equal in size, elongated, ellipsoid

Cell Morphometry - Cells L- 29-36.3 $\mu \mathrm{m}, \mathrm{W}-22-23.1 \mu \mathrm{m}$, I- 6-7.8 $\mu \mathrm{m}$ (Plate C, Figure 16); Occurrence-POND B

Cosmarium leave Rabenhorst: (Coesel \& Meesters, 2007)

Unicellular, variable shape; a constriction at the center, longer than wide, flattened, each semi cell hemispherical, ellipsoidal, rectangular, pyramidal or kidney-shaped, no apical indentation.

Cells Morphometry - L-36-42.5 $\mu \mathrm{m}, \mathrm{W}-24-28 \mu \mathrm{m}, \mathrm{I}-6 \mu \mathrm{m}$ (Plate C, Figure 14-15): Occurrence -Jhada Talab

Cosmarium moniliforme Ralfs: (Coesel \& Meesters, 2007)

Turpin Cells small, globose, semi-cells united by a small neck, cell wall smooth.

Cell Morphometry - L-25.2-26.2 $\mu \mathrm{m}, \mathrm{W}-14.8-15.6 \mu \mathrm{m}, \mathrm{I}$ - 13.315.9 (Plate C, Figure 17); Occurrence -POND B and Jhada talab

Cosmarium subcostatum Ralfs: (Coesel \& Meesters, 2007)

Cell surface granulated, gnarled or spiny, semi cells pyramidal with flattened apex or trapezoid.

Cell Morphometry - L-26-38 $\mu \mathrm{m}, \mathrm{W}-23-32 \mu \mathrm{m}, \mathrm{I}-6.5-12 \mu \mathrm{m}$ (Plate C, Figure 18); Occurrence -Jhada Talab

Journal of Experimental Biology and Agricultural Sciences http://www.jebas.org 


\section{Genus: Euastrum Ehrenberg ex Ralfs 1848}

Euastrum spinulosum Nordstedt: (Coesel \& Meesters, 2007)

Slightly depressed apical region Cell body large; granulated at the center of each semi cell

Cell Morphometry - L-64.5-75.3 $\mu \mathrm{m}, \mathrm{W}-56-64.5 \mu \mathrm{m}$, Constriction 14-17 $\mu \mathrm{m}$ (Plate C, Figure 19); Occurrence -Pond B
Staurastrum tetracerum Ralfs exRalfs: (Coesel \& Meesters, 2007)

Cell small, radiate in apical view, triangular, polygonal

Cell Morphometry: L-12 $\mu \mathrm{m}, \mathrm{W}-12.1 \mu \mathrm{m}$ without processes and with processes $29.3 \mu \mathrm{m}$ length and $27.5 \mu \mathrm{m}$ wide, I - $6.1 \mu \mathrm{m}$ wide (Plate C, Figure 20); Occurrence - Jhada Talab
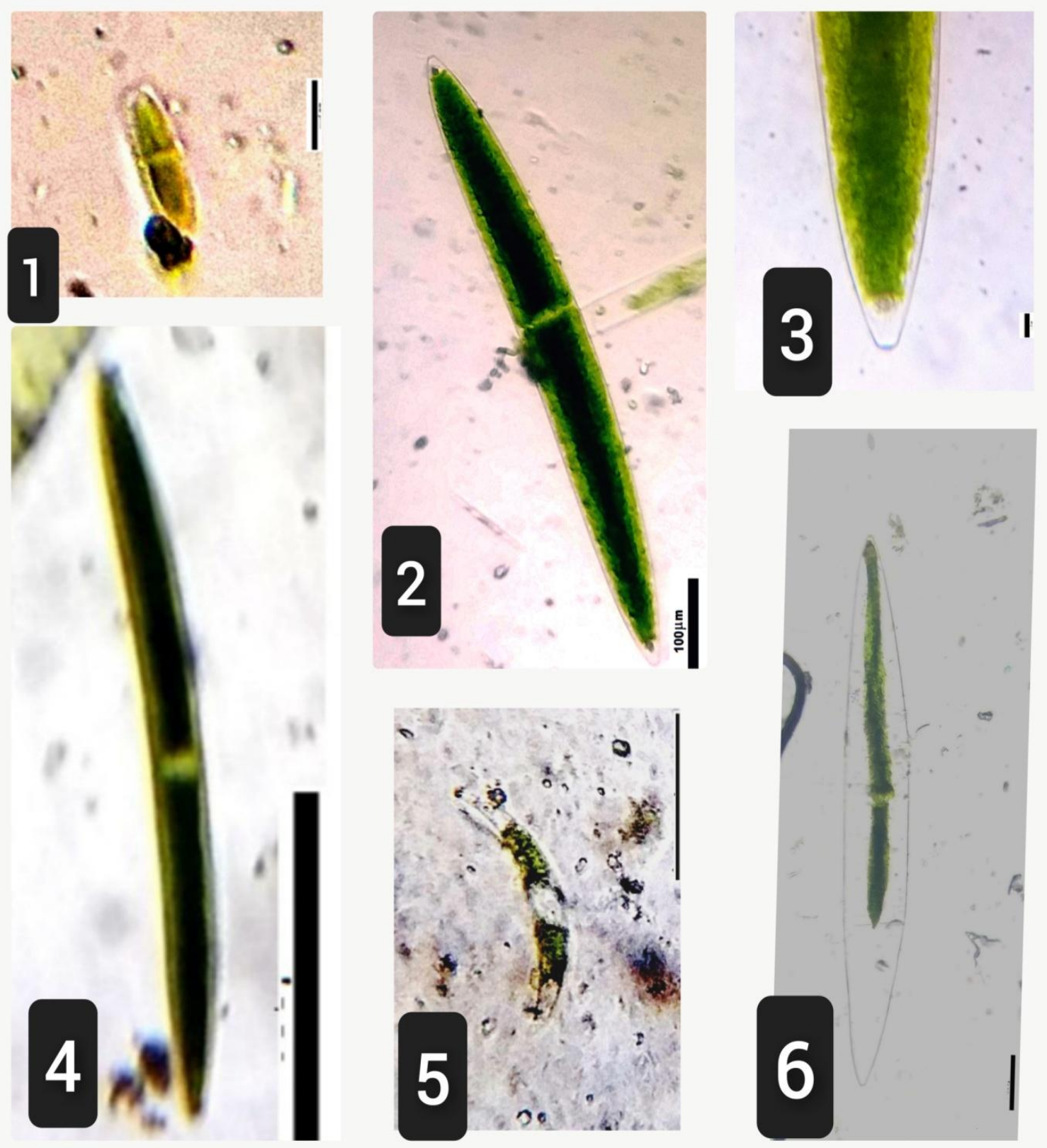

Plate-A - Figure (1) Netrium digitus, (2 -3) Closterium acerosum, (4) Closterium attenuatum, (5) Closterium Cynthia, (6) Closterium pseudo; here lunula Scale bar-100 $\mu \mathrm{m}(10 \mu \mathrm{m}$ for figure $1 \& 3)$

Journal of Experimental Biology and Agricultural Sciences http://www.jebas.org 

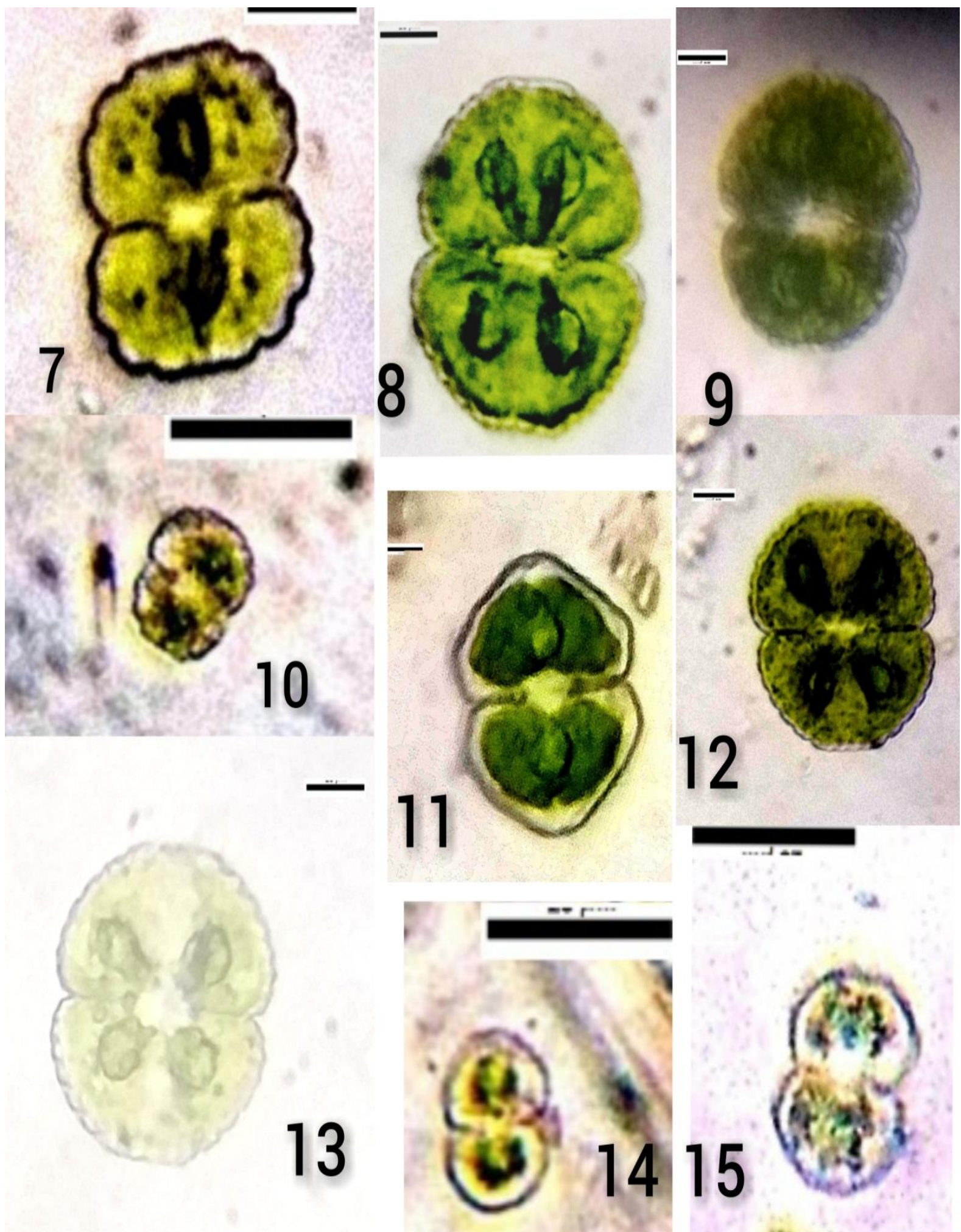

Plate B - Figure (7) Cosmarium blyttii, (8-9) Cosmarium botrytis, (10) Cosmarium crenatum, (11) Cosmarium granatum, (12-13) Cosmarium formosulum, (14-15) Cosmarium leave. here lunula Scale bar-10 $\mu \mathrm{m}$

Journal of Experimental Biology and Agricultural Sciences http://www.jebas.org 

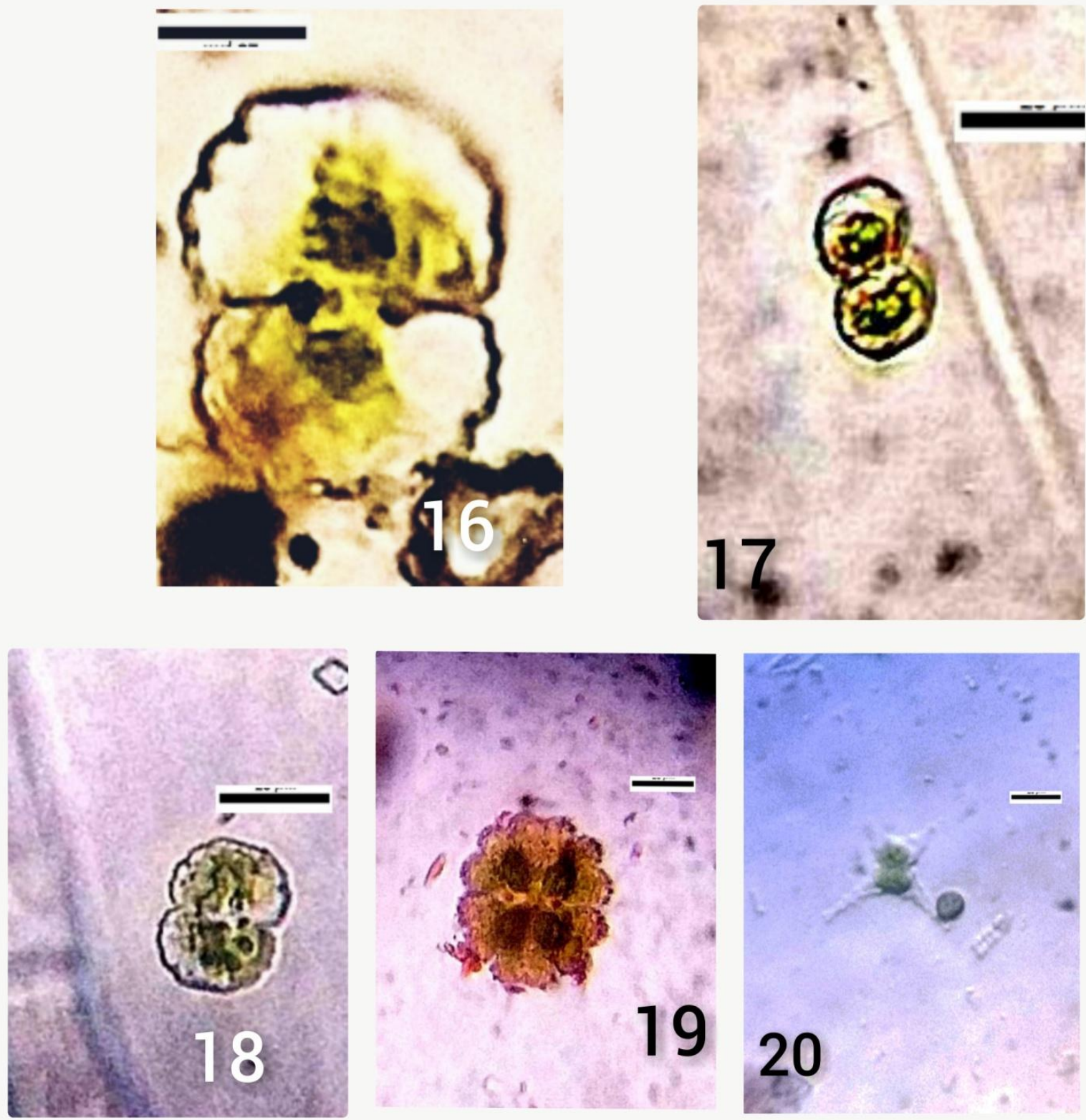

Plate C - Figure (16) Cosmarium impressulum, (17) Cosmarium moniliforme, (18) Cosmarium subcostatum, (19) Euastrum spinulosum (20) Staurastrum tetracerum; here lunula Scale bar - $10 \mu \mathrm{m}$

\section{Discussion and Conclusion}

In the present investigation, 16 species of 5 genera of family Desmidiaceae were reported from the rain-fed Ponds of Nagaur district, western Rajasthan. To the best of our knowledge, these Desmid genera have been reported first time from the aquatic habitat of Nagaur district. Physicochemical analysis of pond water revealed quite variable parameters during the present investigation. In Jhada talab, TDS, total alkalinity, total hardness, chloride, fluoride, nitrate, calcium, and magnesium were found near and above maximum permissible limits of standard drinking water quality of B.I.S. (2012). Besides this, these parameters were found relatively very low and in the acceptable range at all other village ponds. The water $\mathrm{pH}$ was found near and above the acceptable limit at all sampling sites. These results indicate the deteriorating drinking water quality of Jhada talab whether all village ponds have standard quality water for drinking. The reason for this high variation between Jhada Talab and the village pond might be a 
management strategy. Jhada Talab is an urban pond that has been left vulnerable due to ignorance and wastewaters mixing. Besides, the village ponds are an example of community management with clearly defined norms that are closely observed by all villagers to maintain water quality.

Earlier findings have been established a significant relationship between water quality parameters and desmids biodiversity distribution (Coesel, 1983). It has been also observed that high $\mathrm{pH}$ and high calcium concentration have positive relationships with Cosmarium species diversity (Gough, 1977). Similarly, Palmer (1969) included Closterium in the palmer pollution index genera. In the present research work, it was found that nutrient-rich Jhada talab with high $\mathrm{pH}$ and high calcium level has maximum species of Closterium and Cosmarium that were indicated poor water quality. Furthermore, neutral and high $\mathrm{pH}$ with the poor nutrient condition does not support high desmids biodiversity and it was reflected in the village ponds which were oligotrophic in habitat with $\mathrm{pH} 8$ to 9 . In this manner, the results of the current study are in agreement with the findings of previous researchers. The study also determined that Village ponds are good quality water resources and are an example of community management. Results of the study suggested that we must conserve our water restoration technique because human interference and lack of management can destroy our valuable conventional water harvesting technique such as Jhada talab.

\section{Conflicts of Interest: No}

\section{References}

Agarkar DS, Agarker MS, Banerjee S (1983) Desmids of Jabalpur, Madhya Pradesh, India. Cramer: Bibliotheca Phycologia Schweizerbart Science publishers 66: 33-70.

Baird R, Bridgewater L (2017) Standard methods for the examination of water and wastewater. 23rd edition. American Public Health Association, Washington, D.C.

Bureau of Indian Standards (2012) Indian Standard Drinking Water-Specification (Second Revision) IS: 10500;Bureau of Indian Standards (BIS): New Delhi, India.

Coesel PFM (1983) The significance of desmids as indicators of the trophic status of freshwaters. Schweizerische Zeitschriftfür Hydrologie 45(2): 388-393.

Coesel PFM, Krienitz L (2007) Diversity and geographic distribution of desmids and other coccoid green algae. In Foissner W et al. (Eds). Protist Diversity and Geographical Distribution Springer, Dordrecht.
Coesel PFM, Meesters KJ (2007) Desmids of the Lowlands. KNNV Publishing, Zeist.

Gough S (1977) The Growth of Selected Desmid (Desmidiales, Chlorophyta) Taxa at Different Calcium and PH Levels. American Journal of Botany 64 (10): 1297-1299.

Guiry MD, Guiry GM (2021) Algae Base. World-wide electronic publication, National University of Ireland Available at https://www.algaebase.org access on 29 April 2021.

Habib I (2003) Contribution to the acknowledge the desmids of Kumaon Himalaya. In: Ahluwalia AS (Ed.) Phycology Principles Processes and application. Daya publishing house, Delhi.

Hegde GR (1986) Some noteworthy Desmids from Londa, Karnataka State (India). Hydrobiologia 134: 113-115.

Mali MC, Barupal S (2016) Freshwater Chlorophycean diversity of Kodamdesar and Kalyan Sagar ponds of Bikaner region, Rajasthan. Life ScienceBulletin 13(2): 129-134.

Mali MC, Rohitash (2017) Freshwater Chlorococcales diversity of Gajner lake Bikaner (Rajasthan). Life Science Bulletin 14(2): 165168.

Mali MC, Rohitash (2018) studies on freshwater Bacillariophyceae diversity of Gajner Lake Bikaner. Life Science Bulletin 15(1): 11-16.

Neustupa J, Woodard K (2020) Geometric morphometrics reveals increased symmetric shape variation and asymmetry related to lead exposure in the freshwater green alga Micrasterias compereana. Ecological Indicators 111: 106054.

Pachori S, Kumar S (2017) Regional Water Resources Disparities in Rajasthan: A Geographical Analysis. khoj:An International Peer Reviewed Journal of Geography 4( 1): 96- 107.

Palmer CM (1969) A composite rating of algae tolerating organic pollution. Journal of Phycology 5(1): 78-82.

Prescott GW (1976) How to Know the Freshwater Algae. Brown Company Publishers, Dubuque, Lowa.

Ralfs J (1848) The British Desmidieae. Reeve , Benham \& Reeve, London.

Rohitash, Mali MC (2021) Some New Desmids Taxa Reported from Gajner Lake, Bikaner, Rajasthan. Asian Resonance 10(1): 27-32.

Saxena D (2017) Water Conservation: Traditional Rain Water Harvesting Systems in Rajasthan. International Journal of Engineering Trends and Technology 52(2): 91-98. 
Singh SS, Chauhan M (2014) Rainfall Structure of Thar- The great Indian desert. The Scientific report RMC New Delhi and Meteorological Centre, Jaipur.

Stamenković M, Cvijan M (2008) Some new and interesting ecological observations on desmids from the Province of Vojvodina (Northern Serbia). Biologia 63:921-927.

Turner WB (1978) Freshwater Algae of East India (Principally Desmidieae) of East India. Bishen Shingh Mahendra Pal Singh
Publication, Dehradun, India.

West W, West GS (1912) A Monograph of the British Desmidiaceae. Vol. VI. Ray Society, London.

Wilbraham J (2020) Conservation challenges for a microscopic world: Documenting desmids. In The 68th British Phycological Society Meeting, 6-9 January 2020 British Phycological Society Available at http://hdl.handle.net/10141/62286 access on 29 April 2021. 